\title{
Market Analysis of Guava Fruit in District Mardan
}

\author{
Asad Ali Khan ${ }^{1 *}$, Waqas Khan ${ }^{1}$, Shamsher Ali ${ }^{2}$, Wiqar Muhammad ${ }^{1}$, Ijaz Ali Khan ${ }^{3}$, Shah Faisal ${ }^{4}$ and Sidra \\ Bashir $^{5}$
}

${ }^{1}$ Department of Horticulture, The University of Agriculture Peshawar, Pakistan

${ }^{2}$ Department of Soil and Environmental Sciences, The University of Agriculture Peshawar, Pakistan

${ }^{3}$ Department of IBMS, University of Peshawar, Pakistan

${ }^{4}$ Department of Horticulture, Agriculture University of Peshawar, Pakistan

${ }^{5}$ Department of Botany, AWKUM, Pakistan

Submission: March 20, 2018; Published: April 05, 2018

${ }^{*}$ Corresponding author: Asad Ali Khan, Department of Horticulture, The University of Agriculture Peshawar, Village and P.O Dhara Via Lund Khwar Tehsil Takht Bhai Distt Mardan, Pakistan, Tel: +923429797688; Email: asad00658@Gmail.com

\begin{abstract}
The survey was conducted to study "Market analysis of Guava fruit in District Mardan" was carried out in Mardan during 2015. Data were collected for the purpose to determine price fluctuation between whole sellers and retailers and to know about fruit transportation and their loss during marketing. The data were recorded about Guava fruit in Mardan market from whole sellers and retailers from 18 September 2015 to 31 October 2015 with approximately 5 days interval. For data collection fruits main markets of Mardan were visited. During data collection 10 whole sellers and 10 retailers were interviewed on different days to determine price fluctuation between whole sellers and retailers and also on different days and to know about transportation of Guava and their loss during marketing. At the end of survey it was derived that 5-10 rupees difference occurs in overall survey between whole sellers and retailers on different days, it is due to seasonality and a special occasion like Eid. There are about 65-75\% lack of storage in market which causes a huge contribution in losses of Guava. Most of Guava fruits are carried out from Kohat, Balochistan, and Dargai through trucks and other vehicles and fruits are packed in wooden and plastic crates but these are not properly graded and packed. So from this survey it is concluded that marketing of Guava is profitable business after overcoming these problems like, to establish proper storage condition, packing and grading system.
\end{abstract}

Keywords: Guava; Whole sellers; Retailers; Mardan market

\section{Introduction}

Mardan is a district in the Khyber Pakhtunkhwa province of Pakistan. The city of Mardan is the headquarters of the district. The district also contains the famous archaeological site of Takht Bhai, Jamal Ghari and Sawal Dher. The district of Mardan is administratively subdivided into three tehsils, these are: Mardan, Takht Bhai and Katlang [1].

Psidium guajava is one of such medicinal plants belonging to the family Myrtaceae that is also used as a source of food. Pguajava has a rich ethno-medicinal history. Different parts of the plant are used in various indigenous systems of medicine, primarily for the treatment of gastrointestinal disorders [2].

The fruit is sweet and is eaten raw or cooked. It is used to make beverages, ice creams and thickened to prepare jam, jelly or marmalade. Fruits are recommended for gout [3]. The seeds contain $14 \%$ oil on dry weight, with $15 \%$ proteins and $13 \%$ starch [4].
Sufficient and excessive quantities of various fruits and vegetables are grown and produced in Pakistan for its local needs and markets. It is high time for federal Government to initiate several steps to channelize these abundant quantities of fruits and vegetables in international market for export and fetch higher returns to the country and thus to accomplish this important assigned task [5].

It is common perception among the fruit growers that the production per hectare is less in our country as compare to the advanced and developed nations. There are many factors limiting the profitability of cultivation of fruit orchards such as yield, input costs, availability of marketing facilities and absence of any incentive from the government to the peach growers. Other parameters like land, environment of the locality, weather conditions and the location where buying and selling take place may also affect the profitability of growing fruits orchards [6]. 
Post-harvest losses are increases day by day in all over the world and also in Pakistan, There are about 25-40\% losses in fruits annually in Pakistan [7].

\section{Objectives}

i. To determine price fluctuation between whole seller and Retailer of Guava in Mardan market.

ii. To determine problem faced in Mardan market.

\section{Methods and Materials}

Information about fruit prices were collected about guava from fruits whole seller and retailer to determine fruit fluctuation price with whole seller and retailer, fruit transportation and loses of fruits during marketing in main Mardan market and the nature of their work.

\section{Data Collection}

The data were collected about guava fruit in Mardan market of whole seller and retailer. The data were collected from whole seller and retailer from 18 September 2015 to 31 October 2015 with 5 days interval. For data collection I have visited to fruits main market of Mardan. I have tried to my best to conduct the interview in friendly environment so that to collect the correct and reliable information as far possible. During data collection 10 whole seller and 10 retailer were interviewed to determine price fluctuation of fruit on different days and between whole seller and retailer, to know about transportation of fruit and their loses during marketing.

\section{Result and Discussion}

The survey was conducted to study "Market analysis of guava fruit in district Mardan" was carried out in Mardan market during 2015. Data were collected for the purpose of to determine price fluctuation between whole seller and retailer and to know about fruit transportation and their loses during marketing. The following results were obtained in this survey.

\section{Guava in Whole Sale Market}

Table 1: Whole seller price of Guava in Mardan market.

\begin{tabular}{|c|c|c|}
\hline Date & Whole Seller Name & Whole Sale Rate (Rs./Kg) \\
\hline $18-09-2015$ & Islam & 75 \\
\hline $22-09-2015$ & Shazad & 80 \\
\hline $27-09-2015$ & Rahim Gul & 55 \\
\hline $03-10-2015$ & Nazir Khan & 50 \\
\hline $08-10-2015$ & Shaz Ali & 50 \\
\hline $13-10-2015$ & Bahadar & 40 \\
\hline $18-10-2015$ & Umar & 45 \\
\hline $23-10-2015$ & Jehanzeb & 35 \\
\hline $27-10-2015$ & Najeeb & 55 \\
\hline $31-10-2015$ & Suliman & 65 \\
\hline
\end{tabular}

Data was collected on different days with whole seller, the maximum whole sale price of guava was recorded Rs.80per $/ \mathrm{kg}$ on 22 September 2015 with Shahzad whole seller and followed by 75 and 65 per/kg with Islam (18 September) and Suliman (31 October) respectively. While minimum price of guava was recorded Rs.35per/kg on 23 October 2015 with Jahnzeb whole seller and followed by 40 and 45 with Bahadar (13 September) and Umar (18 September) respectively (Table 1).

\section{Guava in Retail Market}

Similarly the maximum retail price of guava was recorded Rs.90per/kg on 22 September 2015 with Anwar and followed by 80 and 75 with Haroon (18 September) and Ashraf (31 October). While minimum retail price of guava was recorded Rs.40per $/ \mathrm{kg}$ on 23 October 2015 with Nawab, followed by 45 and 50per/kg with Gul Badsha (13 October) and Tauseef (18 October).

There are many reason of fluctuation in guava price, one is Eid and second is seasonality. Before Eid the demand of guava was increased and before Eid rate of guava was high in whole sale market and in retail market as in table, but after Eid the price of guava was reduced because of less demand. Present work are agree with the result of [8].

Beside this, price fluctuation occur with whole seller which have no proper storage, and about $65-75 \%$ whole seller have no proper storage so disease and pests attack on them and whole seller provided fruits to retailer on low price and hence a huge fluctuation between whole seller and retailer, and also on different days occur. Current work are agree with the conclusion of [9], as they show that there are about $25-40 \%$ or more losses occur in fruits during post-harvest which ultimately decreases price value of market.

Table 2: Retailer Price of guava in Mardan market.

\begin{tabular}{|c|c|c|}
\hline Date & Retailer Name & Retailer rate (Rs./Kg) \\
\hline $18-09-2015$ & Haroon & 80 \\
\hline $22-09-2015$ & Anwar & 90 \\
\hline $27-09-2015$ & Majid & 60 \\
\hline $03-10-2015$ & Aabid & 55 \\
\hline $08-10-2015$ & Arshad & 55 \\
\hline $13-10-2015$ & Gul Badshah & 45 \\
\hline $18-10-2015$ & Tauseef & 50 \\
\hline $23-10-2015$ & Nawab & 40 \\
\hline $27-10-2015$ & Abdullah & 60 \\
\hline $31-10-2015$ & Ashraf & 70 \\
\hline
\end{tabular}

Table 3: Price Range of guava in Mardan market.

\begin{tabular}{|c|c|}
\hline $\begin{array}{c}\text { Price Range in Whole Sale } \\
\text { Market }\end{array}$ & Price Range in Retail Market \\
\hline $35-80(\mathrm{Rs} . / \mathrm{Kg})$ & $40-90(\mathrm{Rs} . / \mathrm{Kg})$ \\
\hline
\end{tabular}


Sometime Guava are already attack by pests and disses during transportation so whole seller provided it to retailer on lower amount which cause price difference (Table 2,3).

\section{Transportation}

Guava fruits are arrived from Kohat, Dargai and Balochistan to Mardan market. In my point of view the quality and taste of guava fruits which are arrived from Kohat are good as compare to others. It is transported through trucks and other vehicles.

\section{Packing}

Generally Guava are packed in wooden crates, paper cotton etc. one wooden crate consist on 7-9 $\mathrm{kg}$ guava.

\section{Grading}

Guava are graded on the base of size and quality i.e., big and best quality of fruits are graded on the top in the carat while poor quality and small size of guava graded in the bottom.

\section{Problems in the Marketing of Guava in Mardan Market}

In the survey of marketing of Guava in Mardan market the following problems were noted which are faced during marketing.

1. Lack of Transportation Facilities were the main problem which causes losses of Guava during marketing.

2. High costs of Transportation is also a problem.

3. Absence of Regulated Markets.

4. Grading and Packaging system of fruits were very poor.

5. Lack of Storage Facilities is a problem in Mardan market, about $65-70 \%$ whole seller have no proper storage facilities which cause a huge amount of fruit losses.

\section{Conclusion}

On the basis of data collection through interview and presented in various tables, the following conclusion can be drawn.

1. Production and marketing of Guava fruits is normally a profitable business.

2. There are $65-75 \%$ lack of storage facilities in Mardan market.

3. The price of guava are high at the beginning and at the end of season.
4. There will be no effective packing and grading system of Guava in Mardan market which cause price fluctuation and losses in fruit.

5. High fluctuation in the price of Guava occurred at some special occasions like Eid.

6. There are Rs.5-10per/kg difference occur in overall survey between whole seller and retailer.

\section{Recommendations}

1. Due to perishable of Guava fruit most of Guava is wasted. Therefore storage facilities are required for Guava fruits.

2. Grading and packing system should be encouraged in the markets within the country.

3. It is important for government to make such polices which keeps balance in the inflation rate.

4. The hygienic condition of the markets should be improved as in the rainy season it cause more problem for buyers and sellers.

\section{References}

1. Wikipedia. Khyber Pakhtoon khwa, History, Mardan. Wikipedia, the biggest online student website.

2. Begum S, Hassan SI, Siddiqui BS (2002) Two new triterpenoids from the fresh leaves of Psidium guajava. Planta Med 68(12): 1149-1152.

3. Conway, Peter (2001) Tree Medicine, a comprehensive guide to the healing power of over 170 trees. Judy Piatkus (Publishers) Ltd.

4. Burkill HM (1997) The useful plants of West Tropical Africa. ( $\left.2^{\text {nd }} e d n\right)$, Families M-R. Royal Botanic Gardens Kew.

5. Ahmad B, Chaudhry MA, Hassan S (1994) Cost of producing major crops in Punjab. Dept. Farm Management, University of Agriculture, Faisalabad, Pakistan.

6. Bakhsh B, Hassan I, Akhter S (2006) Profitability and cost in growing mango orchards. J Agric Soc Sci 2(1): 46-50.

7. Raja MB, Khokhar KM (1993) Post-harvest Horticulture technology and its future prospects. In proceeding of International Horticulture Seminar. PARC Islamabad, pp. 265-277.

8. Qasim M, Sheikh AD, Muhammad A (2003) Marketing of Guava in Punjab. J Agric Res 42(3-4).

9. Wyk, Ben-Erik V (1997) Oudtshoorn, Bosch van and Gericke, Nigel. Medicinal Plants of South Africa. Briza Publications, Pretoria, South Africa. 
This work is licensed under Creative

Commons Attribution 4.0 License

DOI: 10.19080/JOJHA.2018.01.555559
- Quality Editorial service

- Swift Peer Review

- Reprints availability

- E-prints Service

- Manuscript Podcast for convenient understanding

- Global attainment for your research

- Manuscript accessibility in different formats ( Pdf, E-pub, Full Text, Audio)

- Unceasing customer service

Track the below URL for one-step submission https://juniperpublishers.com/online-submission.php 